\title{
Providencia sneebia sp. nov. and Providencia burhodogranariea sp. nov., isolated from wild Drosophila melanogaster
}

Correspondence
Brian P. Lazzaro
bl89@cornell.edu
Punita Juneja and Brian P. Lazzaro

Department of Entomology, Cornell University, Ithaca, NY 14853, USA

\begin{abstract}
Multiple isolates of the genus Providencia were obtained from the haemolymph of wild-caught Drosophila melanogaster fruit flies. Sixteen isolates were distinguished from the six previously described species based on 16S rRNA gene sequences. These isolates belonged to two distinct groups, which we propose each comprise previously undescribed species. Two isolates, designated $A^{\top}$ and $B^{\top}$, were characterized by DNA sequences of the fus $A$, lepA, leuS, gyrB and ileS housekeeping genes, whole-genome DNA-DNA hybridizations with their nearest relatives and utilization of substrates for metabolism. The closest phylogenetic relatives of strain $A^{\top}$ are strain $\mathrm{B}^{\top}$ (86.9\% identity for the housekeeping genes) and Providencia stuartii DSM $4539^{\top}$ (86.0\% identity). The closest phylogenetic relatives of strain $B^{\top}$ are strain $A^{\top}$ (86.9\% identity) and P. stuartii DSM $4539^{\top}$ ( $86.6 \%$ identity). The type strains of described species in this genus shared between 84.1 and $90.1 \%$ identity for these sequences. DNA-DNA hybridization between the strain pairs $A^{\top}-B^{\top}, A^{\top}-P$. stuartii DSM $4539^{\top}$ and $B^{\top}-P$. stuartii DSM $4539^{\top}$ all resulted in less than $25 \%$ relatedness. In addition, patterns of utilization of amygdalin, arbutin, aesculin, salicin, D-sorbitol, trehalose, inositol, D-adonitol and D-galactose distinguish strains $A^{\top}$ and $B^{\top}$ from other members of this genus. Strains $A^{\top}$ and $B^{\top}$ therefore represent novel species, for which

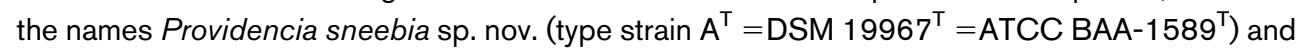
Providencia burhodogranariea sp. nov. (type strain $B^{\top}=$ DSM $19968^{\top}=$ ATCC BAA-1590 $^{\top}$ ) are proposed.
\end{abstract}

The genus Providencia, in the family Enterobacteriaceae, currently has six recognized species. Members of the genus have repeatedly been found in association with humans, insects and many other vertebrate and invertebrate animals in both pathogenic and non-pathogenic contexts (Penner \& Hennessy, 1979; Müller et al., 1986; Yoh et al., 2005; Somvanshi et al., 2006). We describe here two novel Providencia species isolated from the haemolymph of fieldcaptured Drosophila melanogaster fruit flies.

D. melanogaster flies were collected in State College, PA, USA, in 1998 and 2001. Individual flies were surfacesterilized by UV irradiation prior to haemolymph extraction with pulled-glass microcapillary needles. The haemolymph was used to inoculate $1 \mathrm{ml}$ liquid cultures

The GenBank/EMBL/DDBJ accession numbers for the sequences of the $16 \mathrm{~S}$ rRNA, ileS, gyrB, fusA, lepA and leuS genes of the type strains of six described Providencia species and the novel strains are EU587018EU587118, as detailed in Supplementary Table S2.

Details of primers used for PCR amplification of housekeeping genes and sequence accession numbers and a $16 \mathrm{~S}$ rRNA gene sequencebased neighbour-joining tree are available as supplementary material with the online version of this paper. of brain heart infusion (BHI). Liquid cultures were grown aerobically for $24 \mathrm{~h}$ at $37{ }^{\circ} \mathrm{C}$. Enriched cultures were then streaked on BHI agar plates and individual colonies were selected for identification. Seventeen of a total of $337 \mathrm{D}$. melanogaster flies yielded bacterial isolates assignable to the genus Providencia based on partial sequences of the $16 \mathrm{~S}$ rRNA gene, amplified using primers fd1 and $\mathrm{rp} 2$ as described by Weisburg et al. (1991). These isolates clustered into four groups based on partial 16S rRNA gene sequences (978 nt), termed A, B, C and D (Supplementary Fig. S1, available in IJSEM Online). The sole isolate belonging to group $\mathrm{C}$ was subsequently identified as Providencia rettgeri based on its metabolic profile and DNA sequence at housekeeping genes (described below). The remaining isolates did not match described species closely. Isolates $\mathrm{A}^{\mathrm{T}}, \mathrm{A} 75, \mathrm{~A} 91, \mathrm{~A} 101, \mathrm{~A} 102, \mathrm{~B}^{\mathrm{T}}, \mathrm{B} 18, \mathrm{~B} 97, \mathrm{D}$ and D37 were chosen for further characterization. These isolates were compared with the type strains Providencia stuartii DSM $4539^{\mathrm{T}}$, P. alcalifaciens DSM $30120^{\mathrm{T}}$, P. heimbachae DSM $3591^{\mathrm{T}}$, P. rustigianii DSM $4541^{\mathrm{T}}$, P. rettgeri DSM $4542^{\mathrm{T}}$ and P. vermicola DSM $17385^{\mathrm{T}}$, all obtained from the Deutsche Sammlung von Mikroorganismen und Zellkulturen (DSMZ; Braunschweig, Germany). 
Metabolic characteristics were determined from single colonies grown for $24 \mathrm{~h}$ at $37{ }^{\circ} \mathrm{C}$ on Luria-Bertani (LB) agar plates. Metabolic profiles were determined with API $20 \mathrm{E}$ and API 50CH test strips (bioMérieux). Inocula for API 20E strips were prepared in distilled water and inocula for API 50CH strips were prepared using the API $50 \mathrm{CHB} /$ $\mathrm{E}$ medium. Assays were interpreted after $30 \mathrm{~h}$ incubation at $25{ }^{\circ} \mathrm{C}$. Test strips were run at least twice for strains $\mathrm{A}^{\mathrm{T}}$ and $\mathrm{B}^{\mathrm{T}}$ and all of the reference type strains except $P$. rustigianii DSM $4541^{\mathrm{T}}$. Test strips were run once for $P$. rustigianii DSM $4541^{\mathrm{T}}$ and non-type strains of the novel species.
The metabolic profiles of the novel isolates were distinct from each other and from all described Providencia species (Table 1). Results for previously described species varied slightly from published reports by Somvanshi et al. (2006), Farmer et al. (1985) and Hickman-Brenner et al. (1983). These deviations may be due to differences in the test method, temperatures and reaction durations employed by different authors. Isolates $\mathrm{A}^{\mathrm{T}}$, A75, A91, A101 and A102 all had identical metabolic profiles. Isolates $\mathrm{B}^{\mathrm{T}}, \mathrm{B} 18, \mathrm{~B} 97, \mathrm{D}$ and D37 had identical metabolic profiles except for utilization of amygdalin, rhamnose and D-sorbitol, for

\section{Table 1. Differentiation of Providencia strains based on metabolic substrate reactions}

Strains: 1, P. sneebia sp. nov. strains $\mathrm{A}^{\mathrm{T}}$, A75, A91, A101 and A102; 2, P. burhodogranariea sp. nov. strains $\mathrm{B}^{\mathrm{T}}$, B18 and B97; 3, P. burhodogranariea sp. nov. strains D and D37; 4, P. vermicola DSM $17385^{\mathrm{T}}$; 5, P. rettgeri DSM 4542 ${ }^{\mathrm{T}}$; 6, P. stuartii DSM 4539 $9^{\mathrm{T}}$;,$P$. rustigianii DSM $4541^{\mathrm{T}}$; $8, P$. heimbachae DSM $3591^{\mathrm{T}} ; 9$, P. alcalifaciens DSM $30120^{\mathrm{T}}$. All strains were tested under aerobic conditions. Isolates of $P$. sneebia sp. nov. and $P$. burhodogranariea sp. nov. yielded virtually identical results (see text). Each strain was tested at least twice, except $P$. rustigianii DSM $4541^{\mathrm{T}}$ and reference strains of the novel species, which were each tested once. All strains were positive for tryptophan deaminase ${ }^{a_{\dagger}}$ and oxidation/fermentation

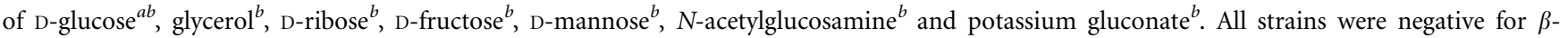
galactosidase $^{a}$, arginine dihydrolase ${ }^{a}$, lysine decarboxylase ${ }^{a}$, ornithine decarboxylase ${ }^{a}, \mathrm{H}_{2} \mathrm{~S}$ production ${ }^{a}$, acetoin production ${ }^{a}$ (given as positive for all strains by Somvanshi et al., 2006), gelatinase ${ }^{a}$ and oxidation/fermentation of melibiose $\mathrm{e}^{a b}$, D- and L-arabinose ${ }^{b}$, L-xylose ${ }^{b}$, methyl $\beta$-Dxylopyranoside $^{b}$, L-sorbose $^{b}$, dulcitol $^{b}$, methyl $\alpha$-D-mannopyranoside ${ }^{b}$, methyl $\alpha$-D-glucopyranoside ${ }^{b}$, amygdalin $^{b}$, cellobiose $^{b}$, lactose $^{b}$, sucrose $^{b}$, inulin $^{b}$, melezitose $^{b}$, raffinose $^{b}$, starch $^{b}$, glycogen $^{b}$, gentiobiose ${ }^{b}$, turanose $^{b}, \mathrm{D}$-tagatose ${ }^{b}, \mathrm{D}$ - and L-fucose ${ }^{b}$ and potassium 5-ketogluconate ${ }^{b}$. Test strips did not give repeatable results within isolates for citrate utilization ${ }^{a}$ and indole production ${ }^{a}$, so results from these assays are not presented. + , Positive; -, negative; v, variable between strains; ?, variable within isolate; w, weak.

\begin{tabular}{|c|c|c|c|c|c|c|c|c|c|}
\hline Characteristic & 1 & 2 & 3 & 4 & 5 & 6 & 7 & 8 & 9 \\
\hline Urease & + & - & - & $?^{z \star}$ & + & - & - & - & - \\
\hline \multicolumn{10}{|l|}{ Utilization of: } \\
\hline L-Arabinose $\mathrm{e}_{\dagger}{ }^{a}$ & - & + & + & + & $\mathrm{w}^{z}$ & - & $\mathrm{w}^{z}$ & - & - \\
\hline D-Adonitol ${ }^{b}$ & - & + & + & + & + & - & - & + & + \\
\hline Amygdalin $^{a}$ & + & - & $\mathrm{V}$ & - & + & - & - & - & - \\
\hline D-Arabitol $^{b}$ & + & + & + & + & + & - & - & + & - \\
\hline $\mathrm{L}-A r a b i t o l^{b}$ & - & - & - & + & + & - & - & $+{ }^{z}$ & - \\
\hline Arbutin $^{b}$ & + & - & - & - & + & - & - & - & - \\
\hline Erythritol $^{b}$ & - & - & - & + & $?^{z}$ & - & - & $+^{z}$ & - \\
\hline Aesculin $^{b}$ & + & - & - & - & $+^{z}$ & - & - & - & - \\
\hline D-Galactose ${ }^{b}$ & - & - & - & + & + & + & + & + & - \\
\hline Inositol $^{a}$ & - & + & + & + & + & $\mathrm{w}$ & - & + & - \\
\hline Inositol $^{b}$ & - & + & + & + & $+^{z}$ & + & - & + & - \\
\hline 2-Ketogluconate ${ }^{b}$ & - & $\mathrm{W}$ & + & + & $+^{z}$ & - & - & $+{ }^{z}$ & - \\
\hline D-Lyxose ${ }^{b}$ & - & - & - & $-{ }^{z}$ & $-{ }^{z}$ & $+^{z}$ & - & $-{ }^{z}$ & - \\
\hline Maltose $^{b}$ & - & - & - & - & - & - & - & $+{ }^{z}$ & - \\
\hline D-Mannitol $^{a}$ & + & + & + & + & + & - & - & - & - \\
\hline D-Mannitol $^{b}$ & + & + & + & + & + & - & - & $-{ }^{z}$ & - \\
\hline L-Rhamnose ${ }^{a}$ & - & - & $\mathrm{V}$ & - & - & + & - & - & + \\
\hline L-Rhamnose ${ }^{b}$ & - & - & - & - & + & - & - & + & - \\
\hline Salicin $^{b}$ & + & - & - & - & + & - & - & - & - \\
\hline D-Sorbitol $^{a}$ & + & $\mathrm{V}$ & $\mathrm{V}$ & - & - & - & - & - & - \\
\hline D-Sorbitol $^{b}$ & + & - & - & - & - & - & - & - & - \\
\hline Sucrose $\mathrm{e}^{a}$ & - & $?$ & $?$ & - & - & - & $-{ }^{y z}$ & - & $-^{z}$ \\
\hline Trehalose $^{b}$ & + & + & + & - & - & $-x y$ & - & - & - \\
\hline Xylitol $^{b}$ & - & - & - & - & - & + & - & - & - \\
\hline D-Xylose $e^{b}$ & $\mathrm{w}$ & - & - & - & - & - & - & - & - \\
\hline
\end{tabular}

${ }^{\star}$ Results differ from those published previously by: $x$, Hickman-Brenner et al. (1983); $y$, Farmer et al. (1985); z, Somvanshi et al. (2006). $\dagger$ Results were determined using the API $20 \mathrm{E}(a)$ or API $50 \mathrm{CH}(b)$ test strip. 
which there was variation among isolates (Table 1). The Providencia species represented by $\mathrm{A}^{\mathrm{T}}$ is uniquely able to utilize D-sorbitol and D-xylose. In contrast to all previously described species of Providencia, isolates $\mathrm{A}^{\mathrm{T}}$ and $\mathrm{B}^{\mathrm{T}}$ are able to utilize trehalose.

Partial sequences of five housekeeping genes ( $f u s A, 616 \mathrm{nt}$; lepA, $735 \mathrm{nt}$; leuS, $412 \mathrm{nt}$; gyrB, $817 \mathrm{nt}$; ileS, $920 \mathrm{nt}$ ) were obtained from ten novel isolates and from the six reference Providencia type strains. Housekeeping genes were amplified and sequenced using a combination of degenerate primers described by Santos \& Ochman (2004) and Providencia-specific custom primers (Supplementary Table S1). PCR products were prepared for sequencing by $1 \mathrm{~h}$ incubation with exonuclease I and shrimp alkaline phosphatase (both from USB Corporation) and sequenced using ABI BigDye Terminator chemistry on an Applied Biosystems Automated 3730 DNA Analyzer. In some cases, amplicons were purified by agarose gel electrophoresis prior to sequencing. Sequences were aligned using CodonCode Aligner (CodonCode Corporation). GenBank/EMBL/DDBJ accession numbers of the new sequences are detailed in Supplementary Table S2. Phylogenetic analysis was performed using MEGA version 3.1 (Kumar et al., 2004) both on alignments of individual genes and on an alignment of a concatenation of all six genes. Distances were calculated based on Jukes-Cantorcorrected percentage divergence and clustering was performed by neighbour-joining. Bootstrap values from 1000 replications were used to assess confidence at each node.

The percentage divergence among type strains of described Providencia species across the concatenated housekeeping genes ranged from $9.9 \%$ between $P$. alcalifaciens DSM $30120^{\mathrm{T}}$ and $P$. rustigianii DSM $4541^{\mathrm{T}}$ to $15.9 \%$ between $P$. stuartii DSM $4539^{\mathrm{T}}$ and P. heimbachae DSM $3591^{\mathrm{T}}$ (Fig. 1). Within group $\mathrm{A}$ of the novel isolates, the maximum observed divergence was $0.3 \%$. Based on this level of sequence similarity, strains $\mathrm{A}^{\mathrm{T}}, \mathrm{A} 75, \mathrm{~A} 91, \mathrm{~A} 101$ and $\mathrm{A} 102$ are considered to belong to the same species. Within groups $\mathrm{B}$ and $\mathrm{D}$ of the isolates, the maximum observed divergence was $0.2 \%$. Isolates of groups $\mathrm{B}$ and $\mathrm{D}$ differed by only $6.3 \%$, lower than the minimum divergence observed between type strains of described Providencia species. Based on their sequence similarity and nearly identical metabolic profiles, strains $\mathrm{B}^{\mathrm{T}}, \mathrm{B} 18, \mathrm{~B} 97, \mathrm{D}$ and D37 are considered to belong to the same species. Strain $B^{T}$ differed from strain $\mathrm{A}^{\mathrm{T}}$ by $13.1 \%$ and from $P$. stuartii $\mathrm{DSM}$ $4539^{\mathrm{T}}$ by $13.4 \%$. Strain $\mathrm{A}^{\mathrm{T}}$ differed from P. stuartii DSM $4539^{\mathrm{T}}$ by $14.0 \%$. These percentage divergence values fall well above the minimum percentage divergence observed between type strains of described Providencia species, supporting the hypothesis that strains $\mathrm{A}^{\mathrm{T}}$ and $\mathrm{B}^{\mathrm{T}}$ represent distinct and novel Providencia species.

DNA-DNA hybridizations were performed between all pairwise combinations of strains $\mathrm{A}^{\mathrm{T}}$ and $\mathrm{B}^{\mathrm{T}}$ and $P$. stuartii DSM $4539^{\mathrm{T}}$, which was inferred to be the nearest described relative based on DNA sequences at the housekeeping genes. DNA isolations and DNA-DNA hybridizations were performed by the DSMZ following the methods described by Cashion et al. (1977), De Ley et al. (1970) and Huß et al. (1983). The reassociation value for the strain pair $\mathrm{A}^{\mathrm{T}}-P$. stuartii DSM $4539^{\mathrm{T}}$ was $13.0 \%$ (mean of 12.7 and $13.3 \%$, obtained from two separate measurements). The reassociation value for the strain pair $\mathrm{B}^{\mathrm{T}}-P$. stuartii DSM $4539^{\mathrm{T}}$ was $18.8 \%$ (mean of 13.8 and $23.8 \%$, obtained from two separate measurements). The reassociation value for the strain pair $\mathrm{A}^{\mathrm{T}}-\mathrm{B}^{\mathrm{T}}$ was $13.1 \%$ (mean of 7.6 and $18.6 \%$, obtained from two separate measurements). Previous studies have reported reassociation values that range from 22 to $49 \%$ between strains of separate species in this genus (Hickman-Brenner et al., 1983; Müller et al., 1986; Somvanshi et al., 2006). The results from the DNA-DNA hybridizations fall well below the $70 \%$ reassociation threshold recommendation of Wayne et al. (1987) for designation of a novel species. These results indicate that strains $\mathrm{A}^{\mathrm{T}}$ and $\mathrm{B}^{\mathrm{T}}$ are significantly distinct from each other and from their nearest described relative in Providencia.

The results from the housekeeping gene sequencing, DNADNA hybridization and metabolic analysis meet the

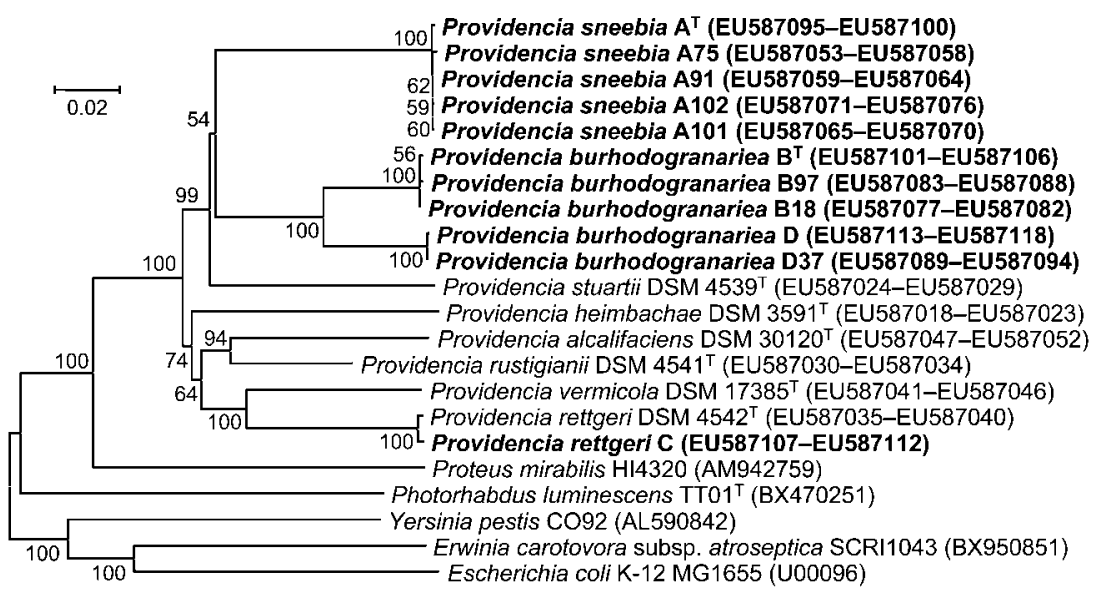

Fig. 1. Neighbour-joining phylogenetic tree based on concatenated sequences from the 16S rRNA gene, fus $A$, lepA, leuS, gyrB and ile $S$ loci (4478 nt) showing the positions of the novel strains within Providencia. Sequences for strains of Proteus mirabilis, Photorhabdus luminescens, Yersinia pestis, Erwinia carotovora and Escherichia coli were obtained from GenBank (accession numbers in parentheses). Bootstrap values on each node are percentages based on 1000 replicates. Bar, 2\% sequence divergence. 
requirements outlined by Wayne et al. (1987) for designating a bacterial species as novel. Based on these results, strains $\mathrm{A}^{\mathrm{T}}, \mathrm{A} 75, \mathrm{~A} 91, \mathrm{~A} 101$ and $\mathrm{A} 102$ belong to a single novel species, for which the name Providencia sneebia sp. nov. is proposed. Likewise, strains $\mathrm{B}^{\mathrm{T}}, \mathrm{B} 18, \mathrm{~B} 97, \mathrm{D}$ and D37 belong to a second novel species, for which the name Providencia burhodogranariea sp. nov. is proposed.

\section{Description of Providencia sneebia sp. nov.}

Providencia sneebia (snee'bi.a. N.L. fem. adj. sneebia of University SNEEB, a series of informal academic gatherings at Cornell University where properties of these bacteria were extensively discussed).

Gram-negative, rod-shaped bacterium. Colonies grown on $\mathrm{LB}$ agar for $48 \mathrm{~h}$ at $37^{\circ} \mathrm{C}$ are up to $4 \mathrm{~mm}$ in diameter, white, opaque, glossy and convex. Growth occurs faster at $37{ }^{\circ} \mathrm{C}$ than at $25{ }^{\circ} \mathrm{C}$. Unique among currently known members of the genus Providencia in being able to produce acid from amygdalin, arbutin, aesculin, salicin, D-xylose, D-sorbitol and trehalose but not from inositol, D-adonitol or D-galactose.

The type strain is $\mathrm{A}^{\mathrm{T}}$ (=ATCC BAA- $1589^{\mathrm{T}}=\mathrm{DSM}$ $19967^{\mathrm{T}}$ ). This and a number of reference strains were isolated from Drosophila melanogaster captured in an apple orchard in State College, PA, USA.

\section{Description of Providencia burhodogranariea sp. nov.}

Providencia burhodogranariea (bu.rho.do.gran.ar'ie.a. Gr. pref. bu- big; Gr. pref. rhodo- red; L. n. granaria a barn; N.L. fem. adj. burhodogranariea of the Big Red Barn, the name of the building where academic discussions of these bacteria were held).

Gram-negative, rod-shaped bacterium. Colonies grown on LB agar for $48 \mathrm{~h}$ at $37{ }^{\circ} \mathrm{C}$ are up to $4 \mathrm{~mm}$ in diameter, white, opaque, glossy and convex. Growth occurs faster at $37{ }^{\circ} \mathrm{C}$ than at $25{ }^{\circ} \mathrm{C}$. After $24-48 \mathrm{~h}$ of growth, colonies express brown pigmentation in their centres. Unique among currently known members of the genus Providencia in being able to produce acid from D-adonitol, trehalose and inositol but not from D-galactose.

The type strain is $\mathrm{B}^{\mathrm{T}}\left(=\mathrm{ATCC}\right.$ BAA $\left.-1590^{\mathrm{T}}=\mathrm{DSM} 19968^{\mathrm{T}}\right)$. This and a number of reference strains were isolated from Drosophila melanogaster captured in an apple orchard in State College, PA, USA.

\section{Acknowledgements}

We would like to thank Madeline Galac and Martin Wiedmann for helpful discussion and advice. We would like to thank the Proteus mirabilis Sequencing Group at the Sanger Institute for early access to the $P$. mirabilis genome sequence. This work was supported by NSF grant DEB-0415851.

\section{References}

Cashion, P., Holder-Franklin, M. A., McCully, J. \& Franklin, M. (1977). A rapid method for the base ratio determination of bacterial DNA. Anal Biochem 81, 461-466.

De Ley, J., Cattoir, H. \& Reynaerts, A. (1970). The quantitative measurement of DNA hybridization from renaturation rates. Eur $J$ Biochem 12, 133-142.

Farmer, J. J., III, Davis, B. R., Hickman-Brenner, F. W., McWhorter, A., Huntley-Carter, G. P., Asbury, M. A., Riddle, C., Wathen-Grady, H. G., Elias, C. \& other authors (1985). Biochemical identification of new species and biogroups of Enterobacteriaceae isolated from clinical specimens. J Clin Microbiol 21, 46-76.

Hickman-Brenner, F. W., Farmer, J. J., III, Steigerwalt, A. G. \& Brenner, D. J. (1983). Providencia rustigianii: a new species in the family Enterobacteriaceae formerly known as Providencia alcalifaciens biogroup 3. J Clin Microbiol 17, 1057-1060.

Huß, V. A. R., Festl, H. \& Schleifer, K. H. (1983). Studies on the spectrophotometric determination of DNA hybridization from renaturation rates. Syst Appl Microbiol 4, 184-192.

Kumar, S., Tamura, K. \& Nei, M. (2004). MEGA3: integrated software for molecular evolutionary genetics analysis and sequence alignment. Brief Bioinform 5, 150-163.

Müller, H. E., O'Hara, C. M., Fanning, G. R., Hickman-Brenner, F. W., Swenson, J. M. \& Brenner, D. J. (1986). Providencia heimbachae, a new species of Enterobacteriaceae isolated from animals. Int $J$ Syst Bacteriol 36, 252-256.

Penner, J. L. \& Hennessy, J. N. (1979). Application of O-serotyping in a study of Providencia rettgeri (Proteus rettgeri) isolated from human and nonhuman sources. J Clin Microbiol 10, 834-840.

Santos, S. R. \& Ochman, H. (2004). Identification and phylogenetic sorting of bacterial lineages with universally conserved genes and proteins. Environ Microbiol 6, 754-759.

Somvanshi, V. S., Lang, E., Sträubler, B., Spröer, C., Schumann, P., Ganguly, S., Saxena, A. K. \& Stackebrandt, E. (2006). Providencia vermicola sp. nov., isolated from infective juveniles of the entomopathogenic nematode Steinernema thermophilum. Int J Syst Evol Microbiol 56, 629-633.

Wayne, L. G., Brenner, D. J., Colwell, R. R., Grimont, P. A. D., Kandler, O., Krichevsky, M. I., Moore, L. H., Moore, W. E. C., Murray, R. G. E. \& other authors (1987). International Committee on Systematic Bacteriology. Report of the ad hoc committee on reconciliation of approaches to bacterial systematics. Int J Syst Bacteriol 37, 463-464.

Weisburg, W. G., Barns, S. M., Pelletier, D. A. \& Lane, D. J. (1991). 16S ribosomal DNA amplification in phylogenetic study. J Bacteriol 173, 697-703.

Yoh, M., Matsuyama, J., Ohnishi, M., Takagi, K., Miyagi, H., Mori, K., Park, K., Ono, T. \& Honda, T. (2005). Importance of Providencia species as a major cause of travellers' diarrhoea. J Med Microbiol 54, 1077-1082. 